\title{
REASSESSMENT OF THE SPINOSE POLYTOECHIID BRACHIOPOD PINATOTOECHIA BENEDETTO FROM THE LOWER ORDOVICIAN OF WESTERN ARGENTINA
}

\author{
JUAN L. BENEDETTO
}

Centro de Investigaciones en Ciencias de la Tierra (CICTERRA), Consejo Nacional de Investigaciones Científicas y Técnicas (CONICET), and Universidad Nacional de Córdoba. Haya de la Torre s/n, Ciudad Universitaria,X5016GCA Córdoba, Argentina. juan.benedetto@unc.edu.ar

Key words. Brachiopods. Billingsellida. Lower Ordovician. W Puna. Famatina. Argentina.

Pinatoechia (type species Pinatotoechia acantha Benedetto, 2001a) is a peculiar spinose polytoechiid hitherto confined to the Famatina-Puna volcanic-arc system fringing the Andean margin of Gondwana during the Ordovician (Benedetto, 1998) (Fig. 1). This genus was originally described from the volcanosedimentary Aguada de la Perdiz Formation exposed west of Salar del Rincón in the Puna region of NW Argentina, a few kilometers from the international border with Chile (Benedetto, 2001a). According to the associated trilobites, as well as the graptolites from correlatable units, the age of these beds is latest Floian-early Dapingian (Koukharsky et al., 1996; Monteros et al., 1996; Brussa et al., 2003; Toro et al., 2015). New and better preserved specimens of Pinatotoechia acantha were subsequently collected from the nearly coeval volcaniclastic Suri Formation of the Famatina Range (Benedetto, 2003) (Fig. 1).

Rubel (2007), in the supplement of the revised Treatise, synonymized Pinatotoechia Benedetto with Tritoechia Ulrich and Cooper, 1936, arguing that the spines of the former are, in fact, identical to the aditicules of the type species Tritoechia typica (Schuchert and Cooper, 1932). The purpose of this paper is to present conclusive evidence on the presence of true hollow spines erected on the tops of costellae in order to support the validity of the genus and to improve its description and illustration. Likewise, the ventral interior of Pinatotoechia is redescribed and reillustrated to show that its pseudospondylium and ventral muscle pattern clearly differ from those of Tritoechia.
High-resolution optical images of spines were obtained using an OLYMPUS LEXT OLS4000 confocal laser scanning microscopy available in the Laboratory of Electronic Microscopy and X-ray Analysis (LAMARX), Consejo Nacional de Investigaciones Científicas y Técnicas and Universidad Nacional de Córdoba, Argentina.

\section{SYSTEMATIC PALEONTOLOGY}

Illustrated specimens are deposited in the paleontological collection of the Centro de Investigaciones en Ciencias de la Tierra (CICTERRA), CONICET-Universidad Nacional de Córdoba. All the types and figured specimens appear with the institutional abbreviation CEGH-UNC.

\section{Class Strophomenata Williams et al., 1996 Order BILLINGSELLIDA Schuchert, 1893 Suborder BILLINGSELLIDINA Öpik, 1934 Superfamily PolytoechioIdeA Öpik, 1932 Family PolytoechiIdae, Öpik, 1934}

Remarks. In this paper we support the criteria exposed by Popov et al. (2001, 2007) and Topper et al. (2013) for recognizing two families among the Polytoechioidea, Tritoechiidae and Polytoechiidae. In the former the entire ventral muscle field rests directly on the floor of the delthyrial cavity or it is raised on a pseudospondylium not undercut anteriorly. In contrast, in the Polytoechiidae the pseu- 
dospondylium is free anteriorly and supported medially and laterally by septa resembling the spondylium triplex of gonambonitids (Vinn and Rubel, 2000). Since Antigonambonites Öpik, 1934, and Raunites Öpik, 1939, formerly attributed to the Gonambonitidae, possess a pseudospondylium of polytoechiid type instead of a true spondylium, Topper et al. (2013) placed them in the family Polytoechiidae. In their phylogenetic analysis Antigonambonites appears, together with Polytoechia Hall and Clarke, 1892, as a derived polytoechiid. As will be shown below, the pseudospondylium of Pinantoechia is undercut anteriorly and supported by a median septum and a pair of lateral septa, and therefore this genus is attributed here to the redefined Family Polytoechiidae. Based on important differences in the ontogeny, Popov et al. (2007) suggested that Polytoechioidea should be placed in the order Billingsellida outside the suborder Clitambonitidina. According to these authors the embrionary development and mode of attachment in the polytoechioidean Antigonambonites Öpik are comparable to those of strophomenates and differ substantially from those of rhynchonellates. Popov et al. (2007) consider that clitambonitidines derived from the order Protorthida, which places them outside the Strophomenata.

\section{Genus Pinatotoechia Benedetto, 2001a}

Type species. Pinatotoechia acantha Benedetto, 2001a. Aguada de la Perdiz Formation, Vega Pinato, western Puna region, Salta Province, NW Argentina.

Emended Diagnosis. Ventribiconvex multicostellate polytoechiid with simple rows of subvertical tubular hollow spines on the top of costellae. Ventral interior with anteriorly free pseudospondylium supported by a median septum and a pair of side septa.

Morphological remarks. Tritoechia typica (Schuchert and Cooper) is the type species of Tritoechia and is characterized by a peculiar ornament of discontinuous swollen hollow costellae. A detail of a dorsal valve bearing such 'tubular

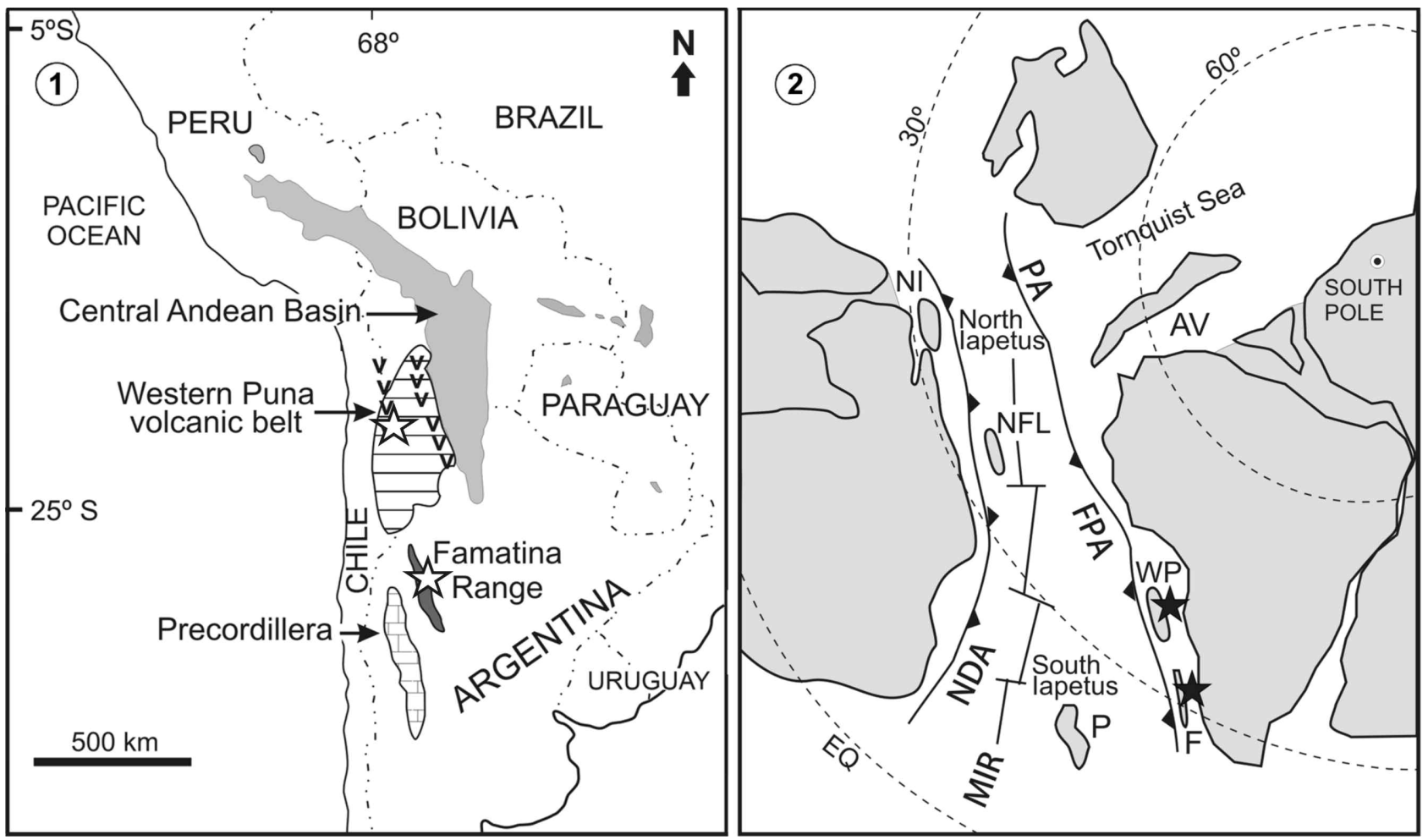

Figure 1. 1, Map of southwestern South America showing the Cambro-Ordovician geological units mentioned in the text showing Pinatotoechia acantha localities (withe stars); 2, Early Ordovician paleogeographic reconstruction of the lapetus Ocean and intervening terranes. AV, Avalonia; F, Famatina Range; FPA, Famatina-Puna volcanic island-arc system; MIR, Mid-lapetus ridge; NDA, Notre Dame arc; NFL, Central Newfoundland; NI, Northwest Ireland; P, Precordillera terrane; PA, Penobscot arc; WP, Western Puna volcanic arc. Black stars: Pinatotoechia acantha occurrences (modified from Benedetto, 1998; lapetus terranes after Harper et al., 1996, and Van Staal et al., 1998). 
costellae' was illustrated by Ulrich and Cooper (1938, pl. 33, fig. 26). It should be noted that this kind of ornamentation is not evident neither in other North American species (Ulrich and Cooper, 1938) nor in species from the Laurentianderived Precordillera terrane (Benedetto, 1987, 2001b), Wales (Neuman and Bates, 1978), Famatina Range (Benedetto, 1994, 2003), Kazakhstan (Popov et al., 2001), Tasmania (Laurie, 1980, 1991) and Iran (Ghobadi Pour et al., 2011), thus this feature is distinctive of the type species only and, as stated before (Benedetto, 1987), it cannot be considered diagnostic of the genus Tritoechia. In the gonambonitid Estlandia marginata (Pahlen, 1877), from the lower Sandbian of Estonia, costellae are crossed by strong growth lamellae which form anteriorly directed arches, or may be directed almost perpendicular to the shell surface and joined anteriorly appearing as a series of holes aligned along ribs; when raised upwards may form short hollow spines (Wright and Rubel, 1996: pl. 2, fig. 5). These authors interpreted the 'tubular costae' of clitambonitoids as aditicules. However, compared with the better known aditicules of plaesiomyids (Jin et al., 2007) there seems to have substantial differences. As defined by these authors, aditicules are proportionally large, anteriorly tilted tubular perforations developed along the crests and slopes of costae or costellae and confined largely to the outer shell layer. The diameter of aditicules measured in the specimen of Plaesiomys anticostiensis (Shaler, 1865) illustrated by Jin et al. (2007: fig. 6.5) is approximately of $75 \mu \mathrm{m}$. Aditicules are always tubular shell perforations and they do not originate spinose structures. Epipunctae are another kind of perforations which are setigerous tubules that can be distinguished from aditicules in their five to ten time smaller sizes and in their uniform distribution on ribs and in interspaces. Epipunctae have not yet been described in the clitambonitidines.

The hollow tubular spines of Pinatotoechia acantha are morphologically comparable to those of the tritoechiid Acanthotoechia hibernica Williams and Curry, 1985. In both species the spines can be viewed as extreme variants of the Estlandia-type 'tubular costellae'. When broken at their base, they appear as a series of subcircular depressions aligned on costellae. However, when preserved complete, the spines are relatively long, subvertical or slightly inclined, sharpened to a point.
Although the dorsal interior of Pinatotoechia is closely comparable to that of Tritoechia and other tritoechiids, some well-preserved ventral internal molds associated to spinose exteriors from both W Puna and Famatina Range clearly show that the anterior portion of the pseudospondylium is free and that it is supported medially by a thick septum and laterally by a pair of subvertical septa, becoming sessile posteriorly (Fig. 2.1-5). On the other hand, the adductor scars are located in a deep, U-shaped median depression separated from the flanking diductor scars by a pronounced break in the slope of the pseudospondylium surface, resembling the muscle pattern of the clitambonitoid Estlandia. The subcircular thickening localized in the posterior third of the pseudospondylium (Fig. 2.3) can be interpreted as a pedicle callist, but another possibility is that it corresponds to the proximal part of a 'pedicle sheath' like that present in juvenile specimens of Antigonambonites planus (Pander, 1830) (Popov et al., 2007); this structure, however, is tubular and much smaller than the scar present in Pinatotoechia.

\section{Pinatotoechia acantha Benedetto, 2001a}

Fig. 2.1-17

Referred material. In addition to the material listed by Benedetto (2001a, 2003), the following new specimens are illustrated: CEGH-UNC 18446 and 18447 from Vega Pinato, western Puna, Salta Province.

Stratigraphic occurrence. Aguada de la Perdiz Formation, western Puna region, upper Floian-lower Dapingian; upper part of the Suri Formation, Famatina Range, Floian (Fig. 1). Description. See Benedetto (2001a) and Benedetto (2003). Diagnosis. The same as the genus by monotopy.

Discussion. The only other known spinose polytoechioid is the monotypic genus Acanthotoechia Williams and Curry, 1985, from the Lower Ordovician Tourmakeady Formation of Ireland. As stated previously (Benedetto 2001a) this genus can be easily distinguished from Pinatotoechia by its definitely parvicostellate ornamentation and its gently concave dorsal valve. Concerning to the ornament, the diameter of tubular spines in Pinatotoechia acantha ranges from 180 to $230 \mu \mathrm{m}$, their maximum measured height is about $460 \mu \mathrm{m}$, and spacing between spines measured along a rib is of 500-600 $\mu \mathrm{m}$. In Acanthotoechia hibernica Williams and 

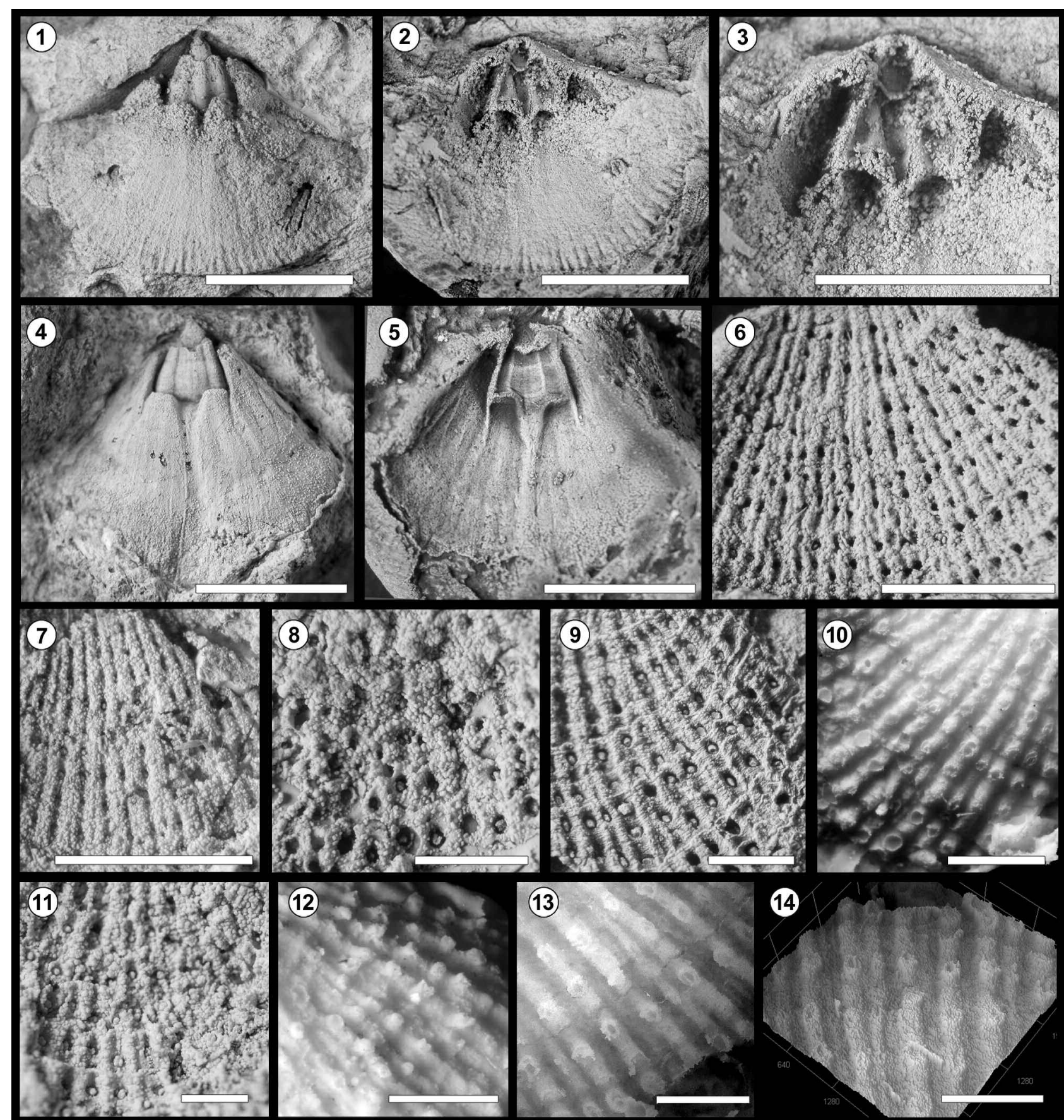

(13)

(14)

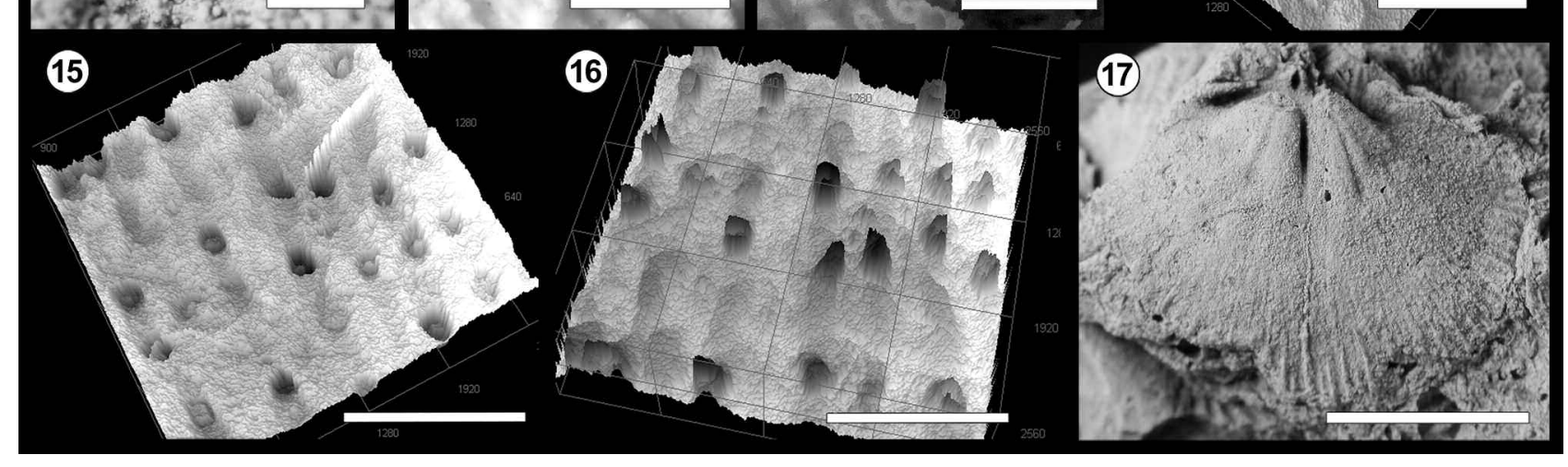


Curry, 1985, the diameter of tubular spines is about three to four times smaller than in P. acantha, those on the primary ribs having a mean diameter of $80 \mu \mathrm{m}$, and those on the finer intercalated ribs of $60 \mu \mathrm{m}$. Moreover, in the Irish genus the primary costellae bear two rows of laterally tilted spines (in anterior view), which near to the anterior margin may be united at their base appearing as bifid (Williams and Curry, 1985: fig. 159); the finer intercalated ribs bear a single row of smaller simple spines.

Internally, the dorsal valve of Acanthotoechia clearly differs from that of Pinatotoechia in having a well-defined subperipheral rim comparable to that of Pomatotrema Ulrich and Cooper in Schuchert and Cooper (1932), Platytoechia Neuman, 1964, and Martellia Wirth, 1936 (Popov et al., 2001; Percival et al., 2009). Unlike Pinatotoechia, the pseudospondylium in Acanthotoechia is entirely sessile and the adductor field is raised on a prominent median ridge. The sessile pseudospondylium supports the assignment of the Irish genus to the family Tritoechiidae.

\section{ACKNOWLEDGMENTS}

I am especially indebted to my colleague N.E. Vaccari who collected the specimens from Vega Pinato making them available for this study. I thank L. Popov for its useful comments leading to the improvement of this paper. I also thank M.R. Romero (LAMARX) and D.F. Muñoz (CICTERRA) for assistance with the photographic images. This research has been supported by grant PIP 112201101-008 from the Consejo Nacional de Investigaciones Científicas y Técnicas (CONICET).

\section{REFERENCES}

Benedetto, J.L. 1987. Braquiópodos clitambonitáceos de la Formación San Juan (Ordovícico temprano), Precordillera de San Juan, Argentina. Ameghiniana 24: 95-108.

Benedetto, J.L. 1994. Braquiópodos Ordovícicos (Arenigiano) de la Formación Suri en la región de Chaschuil, Sistema de Famatina, Argentina. Ameghiniana 31: 221-238.

Benedetto, J.L. 1998. Early Palaeozoic brachiopods and associated shelly faunas from western Gondwana: Its bearing on the geodynamic history of the pre-Andean margin. In: R. Pankhurst, and C.W. Rapela (Eds.), The proto-Andean margin of Gondwana. Geological Society London Special Publications 142: 57-83.

Benedetto, J.L. 2001a. Una fauna de braquiópodos arenigianos (Ordovícico Temprano) en rocas volcaniclásticas de la Puna occidental: Implicaciones paleoclimáticas y paleogeográficas. Ameghiniana 38: 131-146.

Benedetto, J.L. 2001b. Silicified Early Ordovician (Arenig) brachiopods from the San Juan Limestone, Argentine Precordillera. Geologica et Palaeontologica 35: 1-29.

Benedetto, J.L. 2003. Early Ordovician (Arenig) brachiopods from volcaniclastic rocks of the Famatina Range, northwest Argentina. Journal of Paleontology 77: 212-242.

Brussa, E.D., Toro, B.A., and Benedetto, J.L. 2003. Biostratigraphy. In: J.L. Benedetto (Ed.), Ordovician Fossils of Argentina. Secretaría de Ciencia y Tecnología, Universidad Nacional de Córdoba, p. 75-90.

Ghobadi Pour, M., Kebriaee-Zadeh, M.R., and Popov, L. 2011. Early Ordovician (Tremadocian) brachiopods from the Eastern Alborz Mountains, Iran. Estonian Journal of Earth Sciences 60: 65-82.

Hall, J., and Clarke, J.M. 1892. An introduction to the study of the genera of the Palaeozoic Brachiopoda. Geological Survey and Natural History of New York, Palaeontology 8, 367 p.

Harper, D.A.T., Mac Niocaill, C., and Williams, S.H. 1996. The palaeogeography of Early Ordovician lapetus terranes: an integration of faunal and palaeomagnetic constraints. Palaeogeography, Palaeoclimatology, Palaeoecology 121: 297-312.

Koukharsky, M., Torres Claro, R., Etcheverría, M., Vaccari, N.E., and Waisfeld, B.G. 1996. Episodios volcánicos del Tremadociano y Arenigiano en Vega Pinato, Puna salteña, Argentina $13^{\circ} \mathrm{Con}-$ greso Geológico Argentino (Buenos Aires), Actas 5: 535-542.

Jin, J., Zhan, R., Copper, P., and Caldwell, W.G.E. 2007. Epipunctae and phosphatized setae in Late Ordovician plaesiomyid brachiopods from Anticosti Island, eastern Canada. Journal of $\mathrm{Pa}$ leontology 81: 666-683.

Laurie, J.R. 1980. Early Ordovician Orthide brachiopods from southern Tasmania. Alcheringa 4: 11-23.

Laurie, J.R. 1991. Articulate brachiopods from the Ordovician and lower Silurian of Tasmania. In: P.A. Jell (Ed.), Australian Ordovician Brachiopod Studies. Memoirs Association Australasian Palaeontologists 11: 1-106.

Monteros, J.A., Moya, M.C., and Monaldi, C.R. 1996. Graptofaunas arenigianas en el borde occidental de la Puna argentina. Implicancias paleogeográficas. $12^{\circ}$ Congreso Geológico de Bolivia (Tarija), Memorias 2: 733-746.

Neuman, R.B. 1964. Fossils from Ordovician tuffs, northeastern Maine. United States Geological Survey Bulletin 1181E: 1-38

Neuman, R.B., and Bates, D.E.B. 1978. Reassessment of Arenig and Llanvirn age (early Ordovician) brachiopods from Anglesey, north-west Wales. Palaeontology 21: 571-613.

Figure 2. 1-17, Pinatotoechia acantha Benedetto. 1-3, 6, CEGH-UNC 15900 (Famatina Range), ventral internal mold (1), latex cast (2), detail of pseudospondylium (3), and external mold showing spinose ornamentation (6). 4-5, holotype CEGH-UNC 18445 (W Puna), ventral internal mold (4) and latex cast (5). 7, CEGH-UNC 18447 (W Puna), fragmentary ventral external mold. 8, CEGH-UNC 18446 (W Puna), detail of fragmentary ventral external mold. 9-10, CEGH-UNC 15901 (Famatina Range), detail of ventral external mold and latex cast showing hollow spines. 11, CEGH-UNC 18448 (W Puna), fragmentary ventral external mold. 12, latex cast of the external mold illustrated in figure 6, oblique view showing spines. 13-14, latex cast illustrated in figure 12 photographed using confocal laser scanning microscope perpendicular to shell surface (13) and oblique view (14). 15-16, 3D images of the latex cast (oblique views) displayed in the height (15) and unevenness inverted (16). 17, CEGHUNC15847 (Famatina Range), internal mold of dorsal valve. Scale bars 1-6, $17=5 \mathrm{~mm} ; 6,7=2 \mathrm{~mm} ; 8-16=1 \mathrm{~mm}$. 
Öpik, A.A. 1932. Über die Plctellinen. Acta et Commentationes Universitatis Tartuensis, Seies A 23: 1-84.

Öpik, A.A. 1934. Über Klitamboniten. Acta et Commentationes Universitatis Tartuensis, Seies A 36: 1-239.

Öpik, A.A. 1939. Brachiopoden und Ostrakoden aus dem Expansusshiefer Norwegens. Norsk Geologisk Tidsskrift 19: 117-142.

Pahlen, A. von 1877. Monographie der Baltisch-Silurischen Arten der Brachiopoden-Gattung Orthisina. Memoires de l'Académie Imperiale des Sciences de St. Petersbourg 7 (24): 1-52.

Pander, C.H. 1930. Beiträge zur Geognosie des Russischen Reiches. K. Kray. St Petersbourg, 165 p., 31 pl.

Percival, I.G., Wright, A.J., Nicoll, R.S., and Hamedi, M.A. 2009. Martellia and associated Middle Ordovician brachiopods from the Katkoyeh Formation, east-central Iran. Memoirs of the Association of Australasian Palaeontologists 37: 315-325.

Popov, L., Vinn, O., and Nikitina, O.I. 2001. Brachiopods of the redefined family Tritoechiidae from the Ordovician of Kazakhstan and South Urals. Geobios 34: 131-155.

Popov, L.E., Egerquist, E., and Holmer, L.E. 2007. Earliest ontogeny of Middle Ordovician rhynchonelliform brachiopods (Clitambonitoidea and Polytoechioidea): implications for brachiopod phylogeny. Lethaia 40: 85-96

Rubel, M.P. 2007. Clitambonitidina. In: A. Williams et al. (Eds.), Treatise on Invertebrate Paleontology, Part H, Brachiopoda, Revised, volume 6, supplement. The Geological Society of America, Inc. and the University of Kansas. Boulder, Colorado, and Lawrence, Kansas. p. 2680-2681.

Schuchert, Ch. 1893. Classification of the Brachiopoda. American Geologists 11: 141-167.

Schuchert, Ch., and Cooper, G.A. 1932. Brachiopod genera of the suborder Orthoidea and Pentameroidea. Memoirs of the Peabody Museum of Natural History 4: 1-270.

Shaler, N.S. 1865. List of the Brachiopoda from the island of Anticosti sent by the Museum of Comparative Zoology to different institutions for exchange for other specimens, with annotations. Museum of Comparative Zoology Bulletin 1: 61-70.

Topper, T.P., Harper, D.A.T., and Brock, G.A. 2013. Ancestral billingsellides and the evolution and phylogenetic relationships of early rhynchonelliform brachiopods, Journal of Systematic Palaeontology 11: 821-833.

Toro, B.A., Meroi Arcerito, F.R., Muñoz, D.F., Waisfeld, B.G., and de la Puente, G.S. 2015. Graptolite-trilobite biostratigraphy from the Santa Victoria area, north-western Argentina. A key for regional and worldwide correlation of the Early Ordovician (Tremadocian/Floian). Ameghiniana 52: 535-557.
Ulrich, E.O., and Cooper, G.A. 1938. Ozarkian and Canadian brachiopods. Geological Society of America Special Paper 13: 1-323.

Van Staal, C.R., Dewey, J.F., Mac Niocaill, C., and McKerrow, W.S. 1998. The Cambrian-Silurian tectonic evolution of the northern Appalachians and British Caledonides: history of a complex, west and southwest Pacific-type segment of lapetus. In: D.J. Blundell, and A.C. Scott (Eds.), Lyell: the past is the key to the present. Geological Society London, Special Publication 143, p. 199-242.

Vinn, O., and Rubel, M. 2000. The spondylium and related structures in the clitambonitidine brachiopods. Journal of Paleontology 74: 439-443.

Williams, A., and Curry, G.B. 1985. Lower Ordovician Brachiopoda from the Tourmakeady Limestone, Co. Mayo, Ireland. Bulletin of the British Museum (Natural History), Geology 38: 183-269.

Williams, A., Carlson, S.J., Brunton, C.H.C., Holmer, L.E., and Popov, L.E. 1996. A supra-ordinal classification of the Brachiopoda. Philosophical Transactions of the Royal Society of London Series $B$ 351: 1171-1193.

Wirth, E. 1936. Über 'Clitambonites' Giraldii Martelli und Yangtsella Poloi Martelli aus dem Ordoviz Chinas. Paläontologische Zeitschrift 18: 292-303.

Wright, A.D., and Rubel, M. 1996. A review of the morphological features affecting the classification of clitambonitidine brachiopods. Palaeontology 39: 53-75.

doi: 10.5710/AMGH.02.02.2016.2971

Submitted: December $9^{\text {th }}, 2015$

Accepted: February 2 $2^{\text {nd }}, 2016$ 